\title{
Group Coordinator
}

National Cancer Institute

\section{Source}

National Cancer Institute. Group Coordinator. NCI Thesaurus. Code C51827.

A person that is responsible for the integration and interaction of work or events from an assembly of different people with diverse interests and operations. 